\title{
Chemical Compositions of Fermented and Unfermented Seeds of Cissus populnea Obtained from Niger state, Nigeria
}

\author{
J. T. Mathew ${ }^{1 *}$, A. A. Otori ${ }^{2}$, M. Musah ${ }^{1}$, E. Y. Shaba ${ }^{3}$, A. N. Tsado ${ }^{4}$ and E. Tanko ${ }^{3}$ \\ ${ }^{1}$ Department of Chemistry, Ibrahim Badamasi Babangida University Lapai, Niger State. \\ ${ }^{2}$ Department of Chemical Engineering, Federal Polytechnic Bida Niger State. \\ ${ }^{3}$ Department of Chemistry, Federal University of Technology Minna, Niger State, Nigeria \\ ${ }^{4}$ Department of Biological Sciences, Niger State Polytechnics P.M.B. 01, Zungeru, Niger State \\ *Corresponding Author: johntsadom@gmail.com, +2347036068583 \\ Received 20 June 2020; accepted 30 June 2020, published online 06 July 2020
}

\begin{abstract}
:
The chemical compositions of fermented (24 and $48 \mathrm{~h}$ ) and unfermented seeds of Cissus populnea obtained from Niger State, Nigeria were determined using standard analytical methods. The \% total essential amino acids ranged from $37.62 \pm 0.08$ (unfermented) to $40.24 \pm 0.04 \mathrm{~g} / 100 \mathrm{~g}$ protein (fermented for $24 \mathrm{~h}$ ), \% total conditionally essential amino acids ranged from $23.36 \pm 0.10$ (unfermented) to $25.65 \pm 0.05$ (fermented for $24 \mathrm{~h}$ ), while \% total non-essential amino acids ranged from $34.10 \pm 0.07$ (fermented for 24 h) to $39.03 \pm 0.12$ (unfermented) $\mathrm{g} / 100 \mathrm{~g}$ protein. The food functional properties like the foaming capacities ranging from $1.82 \pm 0.12$ (unfermented) to $6.05 \pm 0.10 \%$ (fermented for $48 \mathrm{~h}$ ), oil absorption ranged from $0.65 \pm 0.01$ (unfermented) to $0.70 \pm 0.03 \mathrm{mg} / \mathrm{g}$ (fermented for $48 \mathrm{~h}$ ) and water absorption ranged from $1.89 \pm 0.53$ (fermented for $24 \mathrm{~h}$ ) to $2.03 \pm 0.11 \mathrm{mg} / \mathrm{g}$ (unfermented), bulk densities ranged from $0.39 \pm 0.33$ (fermented for $48 \mathrm{~h}$ ) to $0.61 \pm 0.11 \mathrm{~g} / \mathrm{cm}^{3}$ (unfermented), while swelling capacities ranged from $1.92 \pm 0.28$ (fermented for $48 \mathrm{~h}$ ) to $3.50 \pm 0.36 \%$ (unfermented) and emulsification capacities ranged from $42.03 \pm 0.36$ (unfermented) to $54.21 \pm 0.52 \%$ (fermented for $48 \mathrm{~h}$ ). The physicochemical parameters determined were also observed to decrease as the fermentation days increased. Food processing technologies for exploiting the utilisation of $C$. populnea flours both fermented and unfermented should be promoted.
\end{abstract}

Keywords: Cissus populnea, fermented, unfermented, physicochemical, amino acids

\section{INTRODUCTION}

Recent studies have shown that there are many shrubs and trees in Nigeria; most of them grow fruits containing different seeds and pods that could be explored to increase the available food resources [1]. It is therefore necessary to encourage the use of underutilised species (fruits, vegetables, medicinal plants, starchy crops and condiments) by highlighting their value in their current production areas and by exploring more opportunities to increase their production and consumption [2]. The promotion of these species and the production of their values must be focused on rigorous scientific methods that will allow us to eliminate the stigma of' food for the poor,' which often hinders their popularisation and the creation of new demand. Further development work, including; distribution, conservation, growth, reproduction, post-harvest value-added, nutritional studies as well as consumption as part of a balanced diet, will allow some of these underused species to turn into crops that can support development and quality of life [3].

Cissus populnea Guill et Perr is of the Plantae Kingdom, Ampelidaceae Order, Family of Vitaceae, Genus Cissus and Species: populnea, Hausa: Dafara or latutuwa, Nupe: Egbe.

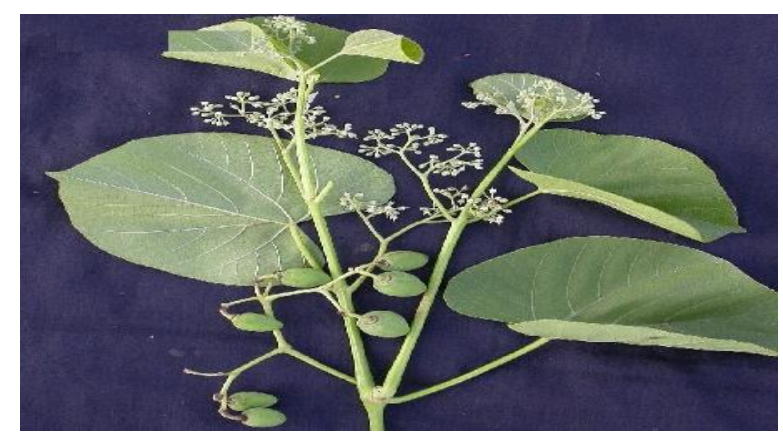

Plate I: Cissus populnea fruit, Source: Field Survey (2018) 
Cissus populnea, Guill's. \& Perr. is a solid woody lame or climbing shrub with a diameter of 8-10 $\mathrm{m}$ and a diameter of $71 / 2 \mathrm{~cm}$. It grows in the savannah and is usually distributed from the coast to the Sudanese and Sahelian forests in West Africa, where it spreads to Senegal and Nigeria. There is plenty of smooth, watery sap when the stems are removed. The flowers are

\section{MATERIALS AND METHODS 2.1 Collection and Sample Preparation}

The seeds of $C$. populnea were obtained from a farmland at Muwo village in Mokwa Local Government Area of Niger State, Nigeria between the months of December and February 2018. Plant was identified and authenticated in the Department of Medicinal Plant Research and Development (MPR\&TM) of National Institute for Pharmaceutical Research and Development, Idu (NIPRD). The cotyledons were removed from the dried seeds manually. The cotyledons obtained from the seeds were further dried to constant weight. $250 \mathrm{~g}$ of $C$. populnea seeds was weighed and crushed into powder with wooden mortar and pestle, sieved with a mesh size 0.5 $\mathrm{mm}$ and stored in well labelled air tight polythene bags for further analysis. The traditional methods of African locust beans fermentation was adopted with modification. $100 \mathrm{~g}$ of C. populnea seeds powder was weighed into $250 \mathrm{~cm}^{3}$ conical flask, $30 \mathrm{~cm}^{3}$ of distilled water was added while $1 \mathrm{~g}$ of yeast (Saccharomyces cerevisiae) were added to the mixture. It was thoroughly mixed, covered and fermented for $24 \mathrm{~h}$. The same process was repeated for the fermentation at $48 \mathrm{~h}$. The fermentation was terminated using freeze dryer and this was kept for further analysis [5][6].

\subsection{Determination of Amino Acid profile}

About $200 \mathrm{mg}$ of the ground seed sample was defatted using chloroform/methanol mixture in a ratio of $1: 1$. From the defatted sample, $30 \mathrm{mg}$ was weighed into a glass ampoule, $7 \mathrm{~cm}^{3}$ of $6 \mathrm{M}$ $\mathrm{HCl}$ was added and oxygen expelled by passing white, and its fruits, when mature, are blackishpurple. The plant has succulent stems that are useful in the construction when dried [4]. The aim of this study is to determine the effect of fermentation on the physico-chemical, food functional properties and amino acids compositions of the seeds of $C$. populnae.

nitrogen into the ampoule. The sealed ampoule was put in the oven at $105{ }^{\circ} \mathrm{C}$ for $22 \mathrm{~h}$, this was allowed to cool and filtered. The filtrate was then evaporated to dryness at $40{ }^{\circ} \mathrm{C}$ under vacuum in a rotary evaporator. The residue was dissolved with $5 \mathrm{~cm}^{3}$ acetate buffer ( $\mathrm{pH} 2.0$ ) and loaded into the amino acid analyzer where the amino acid compositions of the seed samples were determined by Ion Exchange Chromatographic method using the Technicon Sequential Multisample Amino Acid Analyzer [7][8].

\subsection{Physico-chemical Properties of the Oil Samples}

The contents of Peroxide value and viscosity were accounted [9], saponification value and specific gravity were analysed base on the method of Mathew et al. [10]. The procedure of AOAC [8] was used to determine acid value, free fatty acid, temperature, $\mathrm{pH}$ and iodine value.

\subsection{Determination of Food Functional Properties}

The water and oil absorption capacity were analysed base on the method of Ndamitso et al. [11]. The method described by AOAC, [8] was utilised in the analysis of swelling capacity while the foam solubility was calculated after the determination of swelling capacity as per $100 \mathrm{~g}$ of starch on dry basis [12]. Addition of 5 $\mathrm{cm}^{3}$ of aliquot of the supernatant was dried to a constant weight at $120{ }^{\circ} \mathrm{C}$. The procedure of AOAC [8] was used to determine bulk density and gelation properties. 
3. RESULTS AND DISCUSION

The results of the analysis are summarised in Tables 1,2 and 3.

Table 1: Amino acids profile (g/100g protein) of the Samples

\begin{tabular}{llll}
\hline Parameters & Unfermented & Fermented for $24 \mathrm{~h}$ & Fermented for $48 \mathrm{~h}$ \\
\hline Leucine & $9.00 \pm 0.08^{\mathrm{a}}$ & $9.53 \pm 0.07^{\mathrm{b}}$ & $9.64 \pm 0.06^{\mathrm{bc}}$ \\
Lysine & $3.82 \pm 0.07^{\mathrm{a}}$ & $4.72 \pm 0.09^{\mathrm{bc}}$ & $4.42 \pm 0.02^{\mathrm{b}}$ \\
Isoleucine & $3.40 \pm 0.04^{\mathrm{a}}$ & $4.07 \pm 0.07^{\mathrm{bc}}$ & $4.00 \pm 0.07^{\mathrm{b}}$ \\
Phenylalanine & $3.99 \pm 0.04^{\mathrm{a}}$ & $5.02 \pm 0.09^{\mathrm{c}}$ & $4.93 \pm 0.05^{\mathrm{b}}$ \\
Tryptophan & $1.00 \pm 0.06^{\mathrm{a}}$ & $1.03 \pm 0.10^{\mathrm{a}}$ & $1.00 \pm 0.08^{\mathrm{a}}$ \\
Valine & $3.51 \pm 0.05^{\mathrm{a}}$ & $3.90 \pm 0.05^{\mathrm{b}}$ & $4.03 \pm 0.04^{\mathrm{c}}$ \\
Methionine & $1.39 \pm 0.08^{\mathrm{a}}$ & $1.85 \pm 0.10^{\mathrm{bc}}$ & $1.81 \pm 0.02^{\mathrm{b}}$ \\
Histidine & $2.43 \pm 0.02^{\mathrm{a}}$ & $4.03 \pm 0.07^{\mathrm{c}}$ & $3.86 \pm 0.06^{\mathrm{b}}$ \\
Threonine & $3.11 \pm 0.04^{\mathrm{a}}$ & $3.89 \pm 0.02^{\mathrm{bc}}$ & $3.80 \pm 0.08^{\mathrm{b}}$ \\
Cysteine & $1.33 \pm 0.09^{\mathrm{a}}$ & $2.82 \pm 0.02^{\mathrm{b}}$ & $2.83 \pm 0.04^{\mathrm{bc}}$ \\
Proline & $4.06 \pm 0.02^{\mathrm{a}}$ & $4.79 \pm 0.04^{\mathrm{c}}$ & $4.38 \pm 0.05^{\mathrm{b}}$ \\
Arginine & $7.22 \pm 0.02^{\mathrm{bc}}$ & $7.16 \pm 0.08^{\mathrm{b}}$ \\
Tyrosine & $6.19 \pm 0.08^{\mathrm{a}}$ & $4.92 \pm 0.03^{\mathrm{bc}}$ & $4.81 \pm 0.05^{\mathrm{b}}$ \\
Glysine & $3.27 \pm 0.07^{\mathrm{a}}$ & $4.50 \pm 0.03^{\mathrm{b}}$ & $4.88 \pm 0.10^{\mathrm{c}}$ \\
Serine & $3.56 \pm 0.09^{\mathrm{a}}$ & $5.01 \pm 0.05^{\mathrm{c}}$ & $4.72 \pm 0.04^{\mathrm{b}}$ \\
Aspartic acid & $3.73 \pm 0.08^{\mathrm{a}}$ & $10.50 \pm 0.06^{\mathrm{b}}$ & $11.36 \pm 0.07^{\mathrm{c}}$ \\
Glutamic acid & $9.99 \pm 0.10^{\mathrm{a}}$ & $14.01 \pm 0.03^{\mathrm{b}}$ & $14.56 \pm 0.09^{\mathrm{c}}$ \\
Alanine & $13.70 \pm 0.06^{\mathrm{a}}$ & $2.72 \pm 0.06^{\mathrm{a}}$ & $4.61 \pm 0.02^{\mathrm{c}}$ \\
\%TEAA & $3.34 \pm 0.08^{\mathrm{b}}$ & $40.24 \pm 0.04^{\mathrm{c}}$ & $38.73 \pm 0.10^{\mathrm{b}}$ \\
\%TCEAA & $37.62 \pm 0.08^{\mathrm{a}}$ & $25.65 \pm 0.05^{\mathrm{c}}$ & $24.86 \pm 0.04^{\mathrm{b}}$ \\
\%TNEAA & $23.36 \pm 0.10^{\mathrm{a}}$ & $34.10 \pm 0.07^{\mathrm{a}}$ & $36.42 \pm 0.02^{\mathrm{b}}$ \\
\hline & $39.03 \pm 0.12^{\mathrm{c}}$ & & \\
\hline
\end{tabular}

Values in the same row bearing same superscripts are not significantly different at $\mathrm{p} \geq 0.05$

Table 1 shows the result of amino acid compositions $(\mathrm{g} / 100 \mathrm{~g}$ protein) of the fermented and unfermented seeds of $C$. populnea. Amino acids are associated with health issues and their deficiencies lead to a number of diseases. Hence, knowledge of the amino acid composition of foods serves as a basis for establishing their nutritive values [13]. Lysine is an essential amino acid which is extensively required for optimal growth and its deficiency leads to immunodeficiency [14]. It is also used for preventing and treating cold sores [14]. The lysine contents ranged from $3.82 \pm 0.07$ (unfermented) to $4.72 \pm 0.09 \mathrm{~g} / 100 \mathrm{~g}$ protein (fermented for $24 \mathrm{~h}$ ). Prolonged fermentation of up to $48 \mathrm{~h}$ showed significant decrease in the lysine contents of the samples. Okechukwu et al. [15] recorded low lysine concentration for African oil beans ( 0.40 to $1.40 \mathrm{~g} / 100 \mathrm{~g}$ protein for unfermented and fermented samples for 48 h). However, lysine contents were lower than $40.60 \pm 1.10$ (unfermented) to $47.20 \pm 0.30 \mathrm{~g} / 100 \mathrm{~g}$ (fermented for $72 \mathrm{~h}$ ) range reported for Prosopis africana [16].

Leucine is the only dietary amino acid that can stimulate muscle protein synthesis and has important therapeutic role in stress conditions like burn, sepsis and trauma [17]. In this study, leucine concentrations ranged from $9.00 \pm 0.08$ (unfermented) to $9.64 \pm 0.06 \mathrm{~g} / 100 \mathrm{~g}$ protein (fermented for $48 \mathrm{~h}$ ). Results shows progressive increases in the leucine contents of samples as the period of fermentation increased. The increases observed for this amino acid during the fermentation period might have been as a result of the formation of intermediate compounds which during metabolism, reacted with ammonia and were converted to amino acids which in turn were useful in the formation of other amino 
acids [15]. These values were higher than $7.35 \pm 0.05$ (unfermented) to $8.99 \pm 0.10 \mathrm{~g} / 100 \mathrm{~g}$ protein reported for Haematostaphis barteri seed Mathew et al. [7]. Also, Buang and Taib [18] recorded progressive increase in leucine values during the fermentation of groundnut $[1.74 \pm 0.04$ $\mathrm{g} / 100 \mathrm{~g}$ protein (for the fermentation for $18 \mathrm{~h}$ )] to $2.55 \pm 0.01 \mathrm{~g} / 100 \mathrm{~g}$ protein (for $30 \mathrm{~h}$ fermentation), although the values reported were lower compared to the one obtained in this study. The studied plant seeds had leucine content to be lower than $64.50 \pm 2.01$ (unfermented) to $66.50 \pm 2.33 \mathrm{~g} / 100 \mathrm{~g}$ (fermented for $48 \mathrm{~h}$ ) reported for Ricinus communis seed [16]. Therefore, leucine contents in this study plant seeds can greatly contribute to the nutritional composition needed in the body.

The phenylalanine contents ranged from $3.99 \pm 0.04$ (unfermented) to $5.02 \pm 0.09 \mathrm{~g} / 100 \mathrm{~g}$ protein (fermented for $24 \mathrm{~h}$ ). Extension of fermentation period up $48 \mathrm{~h}$ showed significant decrease in the phenylalanine contents of the sample. These values were higher than $1.78 \pm 0.02$ to $2.17 \pm 0.03 \mathrm{~g} / 100 \mathrm{~g}$ protein for unfermented and fermented samples reported for garbanzo beans [18]. However, these values were lower than $6.30 \pm 0.20 \mathrm{~g} / 100 \mathrm{~g}$ protein reported for Anabas testudineus [19]. In addition, 41.60 \pm 3.01 (unfermented) to $67.20 \pm 1.21 \mathrm{~g} / 100 \mathrm{~g}$ protein (fermented for $72 \mathrm{~h}$ ) range was reported for $P$. africana [16]. This is probably because of the different yeast used during fermentation.

Isoleucine is a branched chain amino acid needed for muscle formation and proper growth. Chronic renal failure patients on haemodialysis have low plasma level of the branched chain amino acids such as leucine, valine and isoleucine [20]. The contents of isoleucine in the studied seeds ranged from 3.40 \pm 0.04 (unfermented) to $4.07 \pm 0.07 \mathrm{~g} / 100 \mathrm{~g}$ protein (fermented for $24 \mathrm{~h}$ ). There were significant decreases as fermentation reached $48 \mathrm{~h}$ in the concentrations of isoleucine which might have been as a result of reactions of intermediate compounds formed during metabolism which reacted with ammonia and were converted to amino acids which in turn were useful in the formation of other amino acids [15]. The concentrations of the samples were higher than $0.84 \pm 0.05$ (unfermented) to $1.28 \pm 0.05 \mathrm{~g} / 100 \mathrm{~g}$ protein (fermented for $48 \mathrm{~h}$ ) reported for groundnut seeds [18]. Although, the values were lower compared with $5.41 \mathrm{~g} / 100 \mathrm{~g}$ protein reported for African oil beans [15]. Also, the values were lower compared with the 10.40 $\mathrm{g} / 100 \mathrm{~g}$ protein isoleucine content reported for Stolephorus waitei [19].

Tryptophan which is a precursor for serotonin, melatonin and tryptamine is a brain neurotransmitter theorised to oppress pain. Free tryptophan enters the brain cells to form serotonin. Thus tryptophan supplementation has been used to increase serotonin production in attempt to increase tolerance to pain [21]. The tryptophan contents ranged from $1.00 \pm 0.06$ (unfermented) to $1.03 \pm 0.02 \mathrm{~g} / 100 \mathrm{~g}$ protein (fermented for $24 \mathrm{~h}$ ). These values were higher than $0.65 \mathrm{~g} / 100 \mathrm{~g}$ dietary protein reported for $A$. fasciatus [22]. These were however, lower than the $2.10 \pm 0.50 \mathrm{~g} / 100 \mathrm{~g}$ protein reported for $S$. waitei [19].

Methionine is used for treating liver disorders, improving wound healing and treating depression, alcoholism, asthma, radiation side effects, allergies, copper poisoning, drug withdrawal, Parkinson's disease and schizopherenia [19]. The methionine contents ranged from $1.39 \pm 0.08$ (unfermented) to $1.85 \pm 0.10 \mathrm{~g} / 100 \mathrm{~g}$ protein (fermented for $24 \mathrm{~h}$ ). The increase observed in the methionine concentrations during the fermentation period might have been as a result of formation of intermediate compounds during metabolism which might have reacted with ammonia and converted to amino acids which in turn were useful in the formation of other amino acids [15]. These values were lower compared to reported value of $P$. africana $(10.40 \pm 0.10$ to $13.10 \pm 010 \mathrm{~g} / 100 \mathrm{~g}$ protein for unfermented and fermented for $48 \mathrm{~h}$ ) [16]. These were however, higher than the $1.09 \pm 0.02 \mathrm{~g} / 100 \mathrm{~g}$ protein methionine reported $H$. barteri by Mathew et al. [7].

Valine is needed for muscle metabolism tissue repair and the maintenance of proper nitrogen balance in the body. It is helpful in treating liver 
and gall bladder disorders, and it is good for correcting the type of severe amino acid deficiencies caused by drug addiction [14]. The concentrations of valine ranged from $3.51 \pm 0.05$ (unfermented) to $4.03 \pm 0.04 \mathrm{~g} / 100 \mathrm{~g}$ protein (fermented for $48 \mathrm{~h}$ ). The values obtained in this study were lower than 5.36 (unfermented) to $6.89 \mathrm{~g} / 100 \mathrm{~g}$ protein (fermented for $48 \mathrm{~h}$ ) reported for African oil beans [15]. However, the values were higher compared to the $1.00 \pm 0.13$ (unfermented) to $1.58 \pm 0.06 \mathrm{~g} / 100 \mathrm{~g}$ protein (fermented for $30 \mathrm{~h}$ ) reported for groundnut [18]. They were however, lower than $40.30 \pm 0.80$ (unfermented) to $53.20 \pm 0.60 \mathrm{~g} / 100 \mathrm{~g}$ protein (fermented for $72 \mathrm{~h}$ ) reported for $P$. africana seeds [16].

Histidine plays important roles in protein interaction and is also a precursor of histamine. It is also needed for growth and repair of tissue, for maintenance of the myelin sheaths and in removing heavy metals from the body [23]. The histidine concentrations in the samples of this study ranged from $2.43 \pm 0.02$ (unfermented) to $4.03 \pm 0.07 \mathrm{~g} / 100 \mathrm{~g}$ protein (fermented for $24 \mathrm{~h}$ ). Prolonged fermentation up to $48 \mathrm{~h}$ showed significant decrease in this amino acid in these plant seeds. These values were however, higher than $0.79 \pm 0.01$ (unfermented) to $1.29 \pm 0.02$ $\mathrm{g} / 100 \mathrm{~g}$ protein (fermented for $30 \mathrm{~h}$ ) reported for the garbanzo beans by Buang and Taib [18]. On other hand, they were, lower than the $7.90 \pm 0.60$ $\mathrm{g} / 100 \mathrm{~g}$ protein reported for Rastrelliger kanagurta by Mohanty et al. [19]. In a similar observation, Okechukwu et al. [15] recorded decreased histidine concentrations after the fermentation of African oil beans (1.81 for the unfermented to $1.43 \mathrm{~g} / 100 \mathrm{~g}$ protein for fermented for $48 \mathrm{~h}$ ). This amino acid is very important for the growing and development of infants, therefore incorporation of these plant seeds into infant foods would enhance the growth and development of children particularly in developing nations where animal basedcomplementary foods are expensive.

Threonine is used for treating various nervous system disorders including spinal plasticity, multiple sclerosis, familial, spastic paraparesis and amyotrophic lateral sclerosis [24]. The contents of threonine ranged from $3.11 \pm 0.04$ (unfermented) to $3.89 \pm 0.02 \mathrm{~g} / 100 \mathrm{~g}$ protein (fermented for $24 \mathrm{~h}$ ). From the present study, it is observed that fermentation at $48 \mathrm{~h}$ showed significant decrease in this amino acid in the study plant seeds. From this research, the values of threonine in these samples were higher than the $0.73 \pm 0.03$ (unfermented) to $1.09 \pm 0.03$ $\mathrm{g} / 100 \mathrm{~g}$ protein (fermented for $30 \mathrm{~h}$ ) range reported for groundnut by Bujang and Taib [18]. Also, the values were higher than the $2.54 \pm 0.01$ (unfermented) to $3.06 \pm 0.02 \mathrm{~g} / 100 \mathrm{~g}$ protein (fermented for $48 \mathrm{~h}$ ) range reported for African locust beans flour by Ijarotimi and Keshinro [25].

Glycine plays an important role in metabolic regulation, preventing tissue injury, enhancing anti-antioxidant activity, promoting protein synthesis and wound healing. It also improves immunity and treatment of metabolic disorders in obesity, diabetes, cancer, cardiovascular diseases, ischemia reperfusion injuries and various inflammatory diseases [26]. The concentration of glycine ranged from $3.56 \pm 0.09$ (unfermented) to $4.88 \pm 0.10 \mathrm{~g} / 100 \mathrm{~g}$ protein (fermented for $48 \mathrm{~h}$ ). These values show that this amino acid decreases in concentrations with fermentation period. The glycine values obtained in this work are lower than $5.92 \mathrm{~g} / 100 \mathrm{~g}$ protein reported for Parkia biglobosa [27]. However, they were higher than 1.21 (unfermented) to $1.69 \mathrm{~g} / 100 \mathrm{~g}$ protein (fermented for $48 \mathrm{~h}$ ) range reported for African oil beans by Okechukwu et al. [16].

Arginine plays important role in cell division, wound healing, ammonia removal, immune function and hormone release. It is also the precursor for biological synthesis of nitric oxide which plays important roles in neurotransmission, blood clotting and maintenance of blood pressure [13]. The contents of arginine ranged from $6.19 \pm 0.08$ (unfermented) to $7.22 \pm 0.02 \mathrm{~g} / 100 \mathrm{~g}$ protein (fermented for $24 \mathrm{~h}$ ). The increase observed in arginine contents of the samples with the fermentation period, might have been as a result the formation of intermediate compounds during metabolism which reacted with ammonia and were converted to amino acids which were useful in the formation of other amino acids 
[15]. The values of arginine obtained in this work were higher than $2.74 \pm 0.05 \mathrm{~g} / 100 \mathrm{~g}$ protein reported for A. fasciatus by Furuya et al. [22]. Also, the values were higher compared to the arginine concentration reported for groundnut (2.89 \pm 0.06 unfermented) to $3.04 \pm 0.05 \mathrm{~g} / 100 \mathrm{~g}$ protein (fermented for $30 \mathrm{~h}$ ) by Bujang and Taib [18]. However, the values were lower when compared to the arginine content analysed for $P$. africana seeds flour: $41.60 \pm 1.00$ (unfermented) to $49.00 \pm 0.51 \mathrm{~g} / 100 \mathrm{~g}$ protein (fermented for 72 h) reported by Igwe et al. [16].

The proline contents ranged from 4.06 \pm 0.02 (unfermented) to $4.79 \pm 0.04 \mathrm{~g} / 100 \mathrm{~g}$ protein (fermented for $24 \mathrm{~h}$ ). From the result, it is observed that the contents of this amino acid concentration increased for samples fermented for $24 \mathrm{~h}$ but decreased on fermentation for $48 \mathrm{~h}$, These values were similar compared to 4.09 (unfermented) to the $4.28 \mathrm{~g} / 100 \mathrm{~g}$ protein (fermented for $48 \mathrm{~h}$ ) reported for African locust beans flour by Ijarotimi and Keshinro [25], while the values were higher compared to the $1.50 \pm 0.30 \mathrm{~g} / 100 \mathrm{~g}$ protein reported for Stolephorus commersonii by Mohanty et al. [28]. Although, the values were lower when compared with the $38.00 \pm 0.31 \mathrm{~g} / 100 \mathrm{~g}$ protein reported for $P$. africana by Igwe et al. [16].

The cysteine contents of the plant seeds ranged from $1.33 \pm 0.09$ (unfermented) to $2.83 \pm 0.04$ $\mathrm{g} / 100 \mathrm{~g}$ protein (fermented for $48 \mathrm{~h}$ ). From the result, it can be inferred that the samples had lower values than the $21.20 \pm 0.21 \mathrm{~g} / 100 \mathrm{~g}$ protein reported for $P$. africana by Igwe et al. [16]. However, the values were higher than 0.40 $\mathrm{g} / 100 \mathrm{~g}$ protein (unfermented) to $1.40 \mathrm{~g} / 100 \mathrm{~g}$ protein (fermentation at $48 \mathrm{~h}$ ) reported for African oil beans by Okechukwu et al. [15]. The increased observed in cysteine during the fermentation period might have been as a result of formation of intermediate compounds during metabolism that reacted with ammonia and were converted to amino acids which in turn were useful in the formation of other amino acids [15].

Tyrosine concentration analysed in this samples ranged from $3.27 \pm 0.07$ (unfermented) to $4.92 \pm 0.03 \mathrm{~g} / 100 \mathrm{~g}$ protein (fermented for $24 \mathrm{~h}$ ).
These values were higher compared with $1.18 \pm 0.01 \mathrm{~g} / 100 \mathrm{~g}$ protein reported for $A$. faciatus by Furuya et al. [22]. Also, the values were higher than $0.20 \pm 0.00 \mathrm{~g} / 100 \mathrm{~g}$ protein reported for $S$. commersonii by Mohanty et al. [19]. Although, the values were lower compared with the fermented value of African oil bean reported by Okechukwu et al. [15]. In addition, the values were lower than $33.40 \pm 0.30 \mathrm{~g} / 100 \mathrm{~g}$ protein (unfermented) to $40.60 \pm 0.51 \mathrm{~g} / 100 \mathrm{~g}$ protein (fermentation at $48 \mathrm{~h}$ ) reported for $P$. africana by Igwe et al. [16]. Since these values are high in those samples, they can serve as sources of this amino acid.

The serine concentration of $3.73 \pm 0.08$ (unfermented) to $5.01 \pm 0.05 \mathrm{~g} / 100 \mathrm{~g}$ protein (fermented for $24 \mathrm{~h}$ ). Base on the result of the serine contents analysed in this work, it was recorded that the concentration of this acid increased on fermentation for $24 \mathrm{~h}$, while when fermentation exceeded that period the contents of serine decreased. These results were higher than the respective values of the $1.22 \pm 0.01$ and $1.98 \pm 0.01 \mathrm{~g} / 100 \mathrm{~g}$ protein (for unfermented and fermented for $30 \mathrm{~h}$ ) reported for groundnut seed by Bujang and Taib [18]. They are however, lower than $46.80 \pm 0.60 \mathrm{~g} / 100 \mathrm{~g}$ protein (unfermented) to $64.40 \pm 1.01 \mathrm{~g} / 100 \mathrm{~g}$ protein (fermented for $72 \mathrm{~h}$ ) reported for Prosopis africana by Igwe et al. [16].

Glutamic acid plays an important role in amino acid metabolism because of its role in transamination reactions and is necessary for the synthesis of key molecules, such as polyglutamate folate cofactor and glutathione which are required for the removal of highly toxic peroxides [14]. The glutamic acid values ranged from $13.70 \pm 0.06$ (unfermented) to $14.56 \pm 0.09 \mathrm{~g} / 100 \mathrm{~g}$ protein (fermented for $48 \mathrm{~h}$ ). The values were lower than $102.20 \pm 4.10 \mathrm{~g} / 100 \mathrm{~g}$ protein reported for Prosopis africana by Igwe et al. [16]. Also, the values were lower when compared with $16.90 \mathrm{~g} / 100 \mathrm{~g}$ protein recorded for African oil beans by Okechukwu et al. [15] but these values are higher than the $11.20 \pm 0.07$ (unfermented) to $12.18 \pm 0.03$ (fermented for 24 h) g/100g protein reported for $H$. barteri seed by Mathew et al. [7]. However, African locust beans flour had similar values of $14.82 \pm 0.01$ 
$\mathrm{g} / 100 \mathrm{~g}$ protein as reported by Ijarotimi and Keshinro [25].

The aspartic acid concentration ranged from $9.99 \pm 0.10$ to $11.36 \pm 0.07 \mathrm{~g} / 100 \mathrm{~g}$ protein (fermented for $48 \mathrm{~h}$ ). Similar value was reported for Parkia biglobosa (10.02 g/100 g protein) by Ndamitso et al. [12]. The value obtained in this work were lower than $22.82 \pm 0.01 \mathrm{~g} / 100 \mathrm{~g}$ protein (unfermented) to $23.15 \pm 0.02 \mathrm{~g} / 100 \mathrm{~g}$ protein reported for African locust bean flour by
Ijarotimi and Keshinro [25]. These values were however, high when compared with the $3.64 \pm 0.01 \mathrm{~g} / 100 \mathrm{~g}$ protein reported for $A$. fasciatus by Furuya et al. [22]. Alanine contents ranged from $3.34 \pm 0.08$ (unfermented) to $4.61 \pm 0.02 \mathrm{~g} / 100 \mathrm{~g}$ protein (fermented for $48 \mathrm{~h}$ ). The value obtained in this work is lower compared with the $7.80 \pm 1.10 \mathrm{~g} / 100 \mathrm{~g}$ protein reported for Labeo rohita by Mohanty et al. [19].

\section{Table 2: Food Functional properties of the Samples}

\begin{tabular}{lccc}
\hline Parameters & Unfermented & Fermented for $24 \mathrm{~h}$ & Fermented for $48 \mathrm{~h}$ \\
\hline Bulk density & & & \\
$\left(\mathrm{g} / \mathrm{cm}^{3}\right)$ & $0.61 \pm 0.11^{\mathrm{c}}$ & $0.47 \pm 0.22^{\mathrm{b}}$ & $0.39 \pm 0.33^{\mathrm{a}}$ \\
$\mathrm{EC}(\%)$ & $42.03 \pm 0.36^{\mathrm{a}}$ & $47.14 \pm 0.62^{\mathrm{b}}$ & $54.21 \pm 0.52^{\mathrm{c}}$ \\
$\mathrm{GP}(\%)$ & $33.40 \pm 0.20^{\mathrm{a}}$ & $36.00 \pm 0.67^{\mathrm{b}}$ & $37.89 \pm 0.28^{\mathrm{c}}$ \\
$\mathrm{FC}(\%)$ & $1.82 \pm 0.12^{\mathrm{a}}$ & $3.08 \pm 0.60^{\mathrm{b}}$ & $6.05 \pm 0.10^{\mathrm{c}}$ \\
$\mathrm{WAC}(\mathrm{mg} / \mathrm{g})$ & $2.03 \pm 0.11^{\mathrm{c}}$ & $1.89 \pm 0.53^{\mathrm{a}}$ & $1.96 \pm 0.30^{\mathrm{b}}$ \\
OAC $(\mathrm{mg} / \mathrm{g})$ & $0.65 \pm 0.01^{\mathrm{ab}}$ & $0.68 \pm 0.14^{\mathrm{bc}}$ & $0.70 \pm 0.03^{\mathrm{bc}}$ \\
Foaming stability & & & $106.07 \pm 0.16^{\mathrm{c}}$ \\
$(\%)$ & $98.12 \pm 0.14^{\mathrm{a}}$ & $101.14 \pm 0.22^{\mathrm{b}}$ & \\
Swelling capacity & $3.50 \pm 0.36^{\mathrm{c}}$ & $2.09 \pm 0.18^{\mathrm{b}}$ & $1.92 \pm 0.28^{\mathrm{a}}$ \\
$(\%)$ & Values in the same row bearing same superscripts are not significantly different at $\mathrm{p} \geq 0.05$ \\
\multicolumn{4}{c}{ EC = Emulsification capacity, OAC = Oil absorption capacity, WAC = Water absorption } \\
& capacity, FC = Foaming capacity, GP = Gelation properties
\end{tabular}

The food functional properties of fermented and unfermented samples were presented in Table 2. The swelling index of food determines the amount of water that would be absorbed and the degree of swelling within a stipulated time [29]. This index is influenced by temperature, water availability, carbohydrate and protein [30]. The swelling capacities ranged from $1.92 \pm 0.28$ (fermented for $48 \mathrm{~h}$ ) to $3.50 \pm 0.36$ (unfermented). The decrease in the swelling capacities of the samples with fermentation period obtained in this work might be attributed to the fact that unfermented plant seeds had more of their intermolecular starch bound which allowed them to absorb water and swell more than the fermented samples [31]. The values were higher than $1.41 \pm 0.24$ (unfermented) to $2.05 \pm 0.01 \%$ (fermented for $48 \mathrm{~h}$ ) reported for pigeon pea by Mbaey-Nwaoha and Obetta [32]. Although the values were lower than $4.01 \pm 0.50$ (fermented for $48 \mathrm{~h}$ ) to $6.10 \pm 0.28 \%$ (unfermented) reported for $H$. barteri seeds by Mathew et al [7]. Also, these values were lower than $6.50 \%$ reported by Adebowale and Maliki [33] for unfermented pigeon pea seeds.

Foaming capacity is essential in maintaining constituency, texture and appearance of food that require leavening and aeration properties [29]. The foaming capacities of the plant seeds ranged from $1.82 \pm 0.12$ (unfermented) to $6.05 \pm 0.10$ (fermented). Food ingredients with favourable foaming capacities can be used in bakery products [34]. The increase recorded as the fermentation period increased might have been due to the configurations of the protein molecules as they increase [35]. The foaming capacities were lower than 23.50 $\pm 0.10 \%$ reported for water melon seed by Oyeleke $e t$ al. [36]. Also, the values were lower when compared with $10.00 \pm 0.20 \%$ reported for $P$. biglobosa seeds by Ogunyinka et al. [29]. However, the values were higher than $0.62 \pm 0.02$ $\%$ (unfermented) to $0.92 \pm 0.30 \%$ (fermented for $48 \mathrm{~h}$ ) reported for African oil beans seed by Osagie-Eweka and Alaiya [37]. 
Proteins can function as emulsifiers since they have both hydrophobic and hydrophilic properties that can interact with oil and water in food systems [38]. The emulsification capacities increased significantly with increase in fermentation time with values ranging from $42.03 \pm 0.36$ (unfermented) to $54.21 \pm 0.52 \%$ (fermented for $48 \mathrm{~h}$ ). The increase in the emulsification capacities recorded in this work during the fermentation time could be attributed to the tenability of the protein in the samples to lower the tension at the surfaces of water and oil [39]. The high emulsification capacities obtained from the samples could help in enhancing the additives of these samples in the food industry [36]. However, the values were lower when compared with the $85.00 \pm 4.10 \%$ reported for Cucumeropsis mannii seed flours by Ogunbusola et al. [40]. These values were higher when compared with the $33.33 \pm 0.88$ (unfermented) to $40.24 \pm 0.52 \%$ range reported for African oil seed by Osagie-Eweka and Alaiya [37].

Bulk density explains the packaging requirement and material handling of a food [41]. The bulk densities ranged from $0.39 \pm 0.33$ (fermented for $48 \mathrm{~h}$ ) to $0.61 \pm 0.11 \mathrm{~g} / \mathrm{cm}^{3}$ (unfermented). There was a decrease in these values as the fermentation period increased. This might be as a result of combined interrelated factors such as the intensity of attraction that is poor, interparticle forces, particle size and number of contact points [39]. Similar values were reported for $H$. barteri seed $0.32 \pm 0.41$ (fermented for 48 h) to $0.65 \pm 0.36 \mathrm{~g} / \mathrm{cm}^{3}$ (unfermented) by Mathew et al. [7]. However, the values were lower than $0.80 \pm 0.05 \mathrm{~g} / \mathrm{cm}^{3}$ reported for cowpea as reported by Appiah et al. [42]. Also, the values were low when compared with 0.65 (fermented for $48 \mathrm{~h}$ ) to $0.80 \mathrm{~g} / \mathrm{cm}^{3}$ (unfermented) reported for pigeon pea seed flour by Adebowale and Maliki [33].

Table 3: Physico-chemical Properties of the Oil Extracted from Fermented and Unfermented Seeds of the C.populnea

\begin{tabular}{lccc}
\hline Parameters & Unfermented & $\begin{array}{c}\text { Fermented for } 24 \\
\mathrm{~h}\end{array}$ & $\begin{array}{c}\text { Fermented for 48 } \\
\mathrm{h}\end{array}$ \\
\hline Texture & fine & sticky & sticky \\
Smell & pleasant & irritating & choking \\
Colour & butter & butter & light yellow \\
pH & $5.70 \pm 0.21^{\mathrm{a}}$ & $7.80 \pm 0.31^{\mathrm{b}}$ & $7.80 \pm 0.22^{\mathrm{b}}$ \\
Temperature $\left({ }^{\circ} \mathrm{C}\right)$ & $23.00 \pm 0.21^{\mathrm{a}}$ & $29.00 \pm 0.34^{\mathrm{c}}$ & $27.00 \pm 0.20^{\mathrm{b}}$ \\
Viscosity & $58.65 \pm 0.15^{\mathrm{c}}$ & $55.90 \pm 0.12^{\mathrm{b}}$ & $51.55 \pm 0.42^{\mathrm{a}}$ \\
Iodine value $(\mathrm{gI} / 100 \mathrm{~g})$ & $46.03 \pm 0.20^{\mathrm{c}}$ & $42.10 \pm 0.10^{\mathrm{b}}$ & $39.72 \pm 0.32^{\mathrm{a}}$ \\
PV $($ Meq KOH$/ \mathrm{g})$ & $2.82 \pm 0.12^{\mathrm{c}}$ & $2.19 \pm 0.51^{\mathrm{b}}$ & $1.89 \pm 0.22^{\mathrm{a}}$ \\
SV (mg KOH/g) & $72.33 \pm 0.41^{\mathrm{a}}$ & $80.25 \pm 0.30^{\mathrm{b}}$ & $82.17 \pm 0.25^{\mathrm{c}}$ \\
Specific gravity & $0.90 \pm 0.10^{\mathrm{c}}$ & $0.87 \pm 0.25^{\mathrm{b}}$ & $0.83 \pm 0.11^{\mathrm{a}}$ \\
Acid value $(\mathrm{mg} \mathrm{KOH} / \mathrm{g})$ & $2.44 \pm 0.50^{\mathrm{c}}$ & $2.01 \pm 0.43^{\mathrm{b}}$ & $1.69 \pm 0.23^{\mathrm{a}}$ \\
Refractive index & $1.4557 \pm 0.18^{\mathrm{ab}}$ & $1.4562 \pm 0.22^{\mathrm{bc}}$ & $1.4564 \pm 0.24^{\mathrm{bc}}$ \\
FFA (mg KOH/g) & $1.22 \pm 0.21^{\mathrm{c}}$ & $1.00 \pm 0.23^{\mathrm{b}}$ & $0.85 \pm 0.32^{\mathrm{a}}$ \\
\hline Val in & & &
\end{tabular}

Values in the same row bearing same superscripts are not significantly different at $\mathrm{p} \geq 0.05$

$\mathrm{SV}=$ saponification value, $\mathrm{PV}=$ Peroxide value, $\mathrm{FFA}=$ Free fatty acid

The results of the physicochemical properties of oils obtained from the fermented and unfermented seeds of the $C$. populnea were presented in Table 3. The oils extracted were 
butter in colour for unfermented and fermented for $24 \mathrm{~h}$, while light yellow in colour for fermented at $48 \mathrm{~h}$. Adejumo et al. [43], recorded similar colours during the fermentation of $P$. biglobosa seeds. The textures observed during the fermentation of the plant seeds were fine before fermentation, while sticky were observed for samples fermented for 24 and $48 \mathrm{~h}$. The fermented plant seeds of P. biglobosa showed similar texture reported by Adejumo et al. [43]. The smell properties observed in this study were pleasant before fermentation, while irritating smell observed for the samples fermented for 24 $\mathrm{h}$ and for samples fermented for $48 \mathrm{~h}$ had chocking.

The low iodine values of the oils indicated that they have low contents of unsaturated fatty acids. This showed that these oils will not be susceptible to oxidative deterioration and thus they can be easily stored for a long time without spoilage [44]. The iodine contents ranged from $39.72 \pm 0.32$ (fermented for $48 \mathrm{~h}$ ) to $46.03 \pm 0.20$ $\mathrm{gI}_{2} / 100 \mathrm{~g}$ (unfermented). There was a decrease generally in iodine values of the oil samples content in this study as the period of fermentation increased. This may be as a result of decrease in fat contents that might have been converted to protein by the help of microorganisms present during fermentation. The values were low compared to $81.94 \pm 1.03$ $\mathrm{gI}_{2} / 100 \mathrm{~g}$ reported for groundnut oil (gargajiya) by Nkafamiya et al. [45]. They were however higher than $38.71 \mathrm{gI}_{2} / 100 \mathrm{~g}$ reported for groundnut oil by Atasie et al. [46].

Saponification value is used in checking adulteration [47]. The saponification value is a measure of the alkali reactive groups in fats and oils and is expressed as the number of milligrammes of potassium hydroxide which react with one gramme of sample [48]. The saponification values ranged from $72.33 \pm 0.41$ (unfermented) to $82.17 \pm 0.25$ (fermented for 48 h). These values were lower than $179.04 \pm 1.60$ $\mathrm{mgKOH} / \mathrm{g}$ reported for the seed oil of Telfairia occidentalis by Bello et al. [49]. The acid value of oil is a direct measure of the percentage content of free fatty acids in a given amount of the oil. It is a measure of the extent to which the triglycerides in the oil is decomposed into free fatty acids by lipase action. This value depends on the degree of rancidity which is used as an index of freshness [50]. The acid values ranged from $1.69 \pm 0.23$ (fermented for $48 \mathrm{~h}$ ) to $2.44 \pm 0.50 \mathrm{mgKOH} / \mathrm{g}$ (unfermented). These values were higher than $1.48 \pm 1.60 \mathrm{mgKOH} / \mathrm{g}$ reported for seed oil of Telfairia occidentalis by Bello et al. [49]. However they were lower compared to pea nut oil of bari $(8.89 \pm 0.32$ $\mathrm{mgKOH} / \mathrm{g}$ ) reported by Shad et al. [51]. The low acid value obtained in this study gives an indication of their lower susceptibility to rancidity which depicts a higher shelf life [10].

The peroxide value of oil is a sign of its rancidity, thus a high peroxide value of oil indicates a poor resistance of the oil to peroxidation during storage [52]. Higher peroxide values between 20 and 40 results in a rancid taste while the low peroxide value further confirms the stability of the oil [53]. The peroxide values ranged from $1.89 \pm 0.22$ (fermented for $48 \mathrm{~h}$ ) to $2.82 \pm 0.12 \mathrm{Meq} \mathrm{KOH} / \mathrm{g}$ (unfermented). These values obtained in this work are lower than $5.26 \pm 0.06 \mathrm{Meq} \mathrm{KOH} / \mathrm{g}$ reported for T. occidentalis by Bello et al. [49]. They are however higher than $1.50 \mathrm{Meq} \mathrm{KOH} / \mathrm{g}$ reported for groundnut oil by Atasie et al. [46]. The peroxide values obtained from this work indicate that, these oils will take long time before they deteriorate.

The refractive index of oil indicates the level of optical clarity of the oil sample relative to water. The refractive indices of oils obtained for unfermented plant seeds ranged from $1.4557 \pm 0.18$ (unfermented) to $1.4564 \pm 0.24$ (fermented for $48 \mathrm{~h}$ ). A similar index of $1.460 \pm 0.08$ was reported for $T$. occidentalis by Bello et al. [49]. However, the samples had higher values when compared to the value reported for groundnut oil (1.449) by Atasie et al. [46]. This implies that the oils obtained from this plant seeds are lighter and could be considered to be of high quality and as such find much use in the pharmaceutical industries. Free fatty acids are more susceptible to lipid oxidation, leading to rancidity and production of off-odour compared to intact fatty acids in the triglycerides [48]. The free fatty acid values ranged from $0.85 \pm 0.32$ (fermented for $48 \mathrm{~h}$ ) to $1.22 \pm 0.25 \mathrm{mgKOH} / \mathrm{g}$ (unfermented). Similar 
value of $3.01 \mathrm{mg} / \mathrm{KOH} / \mathrm{g}$ was reported for groundnut oil by Atasie et al. [46]. However, these values are higher than $1.74 \pm 0.49$ $\mathrm{mgKOH} / \mathrm{g}$ reported for seed oil $T$. occidentalis by Bello et al. [54]. Since the values obtained from this work is low, it is implied that the oils obtained from these selected plant seeds will take more time before susceptible to lipid oxidation and rancidity.

\section{CONCLUSION}

Results from this study revealed adequate chemical compositions fermented and unfermented necessary for building the body. The flours possess good functional properties which can be incorporated into human diets not only as protein supplements but also as in processed foods like weaning, baked and soup products. Food processing technologies for exploiting the utilisation of $C$. populnea flours both fermented and unfermented should be promoted.

\section{CONFLICT OF INTEREST}

There is no conflict of interest associated with this work.

\section{REFERENCES}

[1] J.O. Popoola and O.O. Obembe (2013), Local knowledge, use pattern and geographical distribution of Moringa oleifera Lam. (Moringaceae) in Nigeria. Journal of Ethnopharmacology, 150, 682691.

[2] A.W. Ebert (2014), Potential of underutilized traditional vegetables and legume crops to contribute to food and nutritional security, income and more sustainable production systems. Sustainability, 6, 319-335.

[3] M.O. Bello (2014), Nutrient potentials of underutilised plant species in Nigeria. Accra, Ghana: United Nations University Institute for Natural Resources in Africa.

[4] H.M. Burkill (2000), The useful plants of West Tropical Africa, 5. Royal Botanic
Gardens, Kew, 296-297. How did we get here? 2020 Discussion paper 37. International Food Policy Research Institute, 23, 44-47.

[5] J.T. Mathew, B.E.N. Dauda, A. Mann. M.M. Ndamitso, A.L. Fadipe and E.Y. Shaba (2018), Assessment of Nutritional Properties of Fermented and Unfermented Seed of Cissus populnae From Niger State, Nigeria. Assumption University-eJournal of Interdisciplinary Research, 3, 70-77.

[6] M.B. Etsuyankpa, J.T. Mathew, M.M. Ndamitso, O. Baba, O.D. Opaluwa and A.B. Salihu (2019), Evaluation of Chemical Nutritional Composition of African pear pulp Obtained from Mararaba Jamma Market Jos, Plateau State. Nigerian Journal of. Chemical Research, 24, $42-55$.

[7] J.T. Mathew, B.E.N. Dauda, A. Mann, M.M. Ndamitso, M.B. Etsuyankpa and M.B. Nasirudeen (2018), Nutrient And AntiNutrient Assessment of Fermented and Unfermented Seed of Haematostaphis barteri from Niger State, Nigeria. International Journal of Applied and Biological Research, 9, 55 - 66.

[8] AOAC (Association of Official Analytical Chemists), (2006), Official Methods of Analysis (15th ed.). Washington DC., USA: AOAC Press.

[9] J.T. Mathew, B.E.N. Dauda, Y.B. Paiko, M.M. Ndamitso and S. Mustapha (2013), Phytochemical, Anti-Nutritional and Physicochemical Properties of Sugar Ant (Componotus consubrinus). Continental Journal of Food Science and Technology. 7, $39-45$.

[10]J.T. Mathew, M.M. Ndamitso, E.Y. Shaba, S. Mustapha, S.S. Muhammed and A.S. Salihu (2014), Physicochemical and Phytochemical Composition of locust bean tree emperor moth larvae (Bunaea alcinoe) from Gurara Local Government Area, Niger 
state, Nigeria. International Journal of Engineering Science Invention, 3, 14-18.

[11] M.M. Ndamitso, M.B. Etsunyakpa, J.O. Jacob, J.T. Mathew, E.Y. Shaba and C. Olisedeme (2015), The Nutritional Values and Functional Properties of Wild Ipomoea (Water Spinach) found in the Fadama Areas of Minna, Niger state, Nigeria, Academic Research International 6, 1-8.

[12] M.M. Ndamitso, M. Musah, J.T. Mathew and V.T. Bissala (2020), Comparative Nutritional Analysis of Daddawa Made from Fermented Parkia biglobosa and Glycine max Seeds. Comminication in Physical Science, 5, 263269.

[13] D. Sarma, M.S. Akhtar and P. Das (2013), Nutritional quality in terms of amino acid and fatty acid of five coldwater fish species: Implications to human health. National Academy Science Letters, 36, 385391.

[14] G. Wu (2013), Functional amino acids in nutrition and health. Amino Acids, 45, 407-411.

[15] R.I. Okechukwu, N.C. Ewelike, A.A. Ukaoma, A. A. Emejulu and C.O. Azuwike (2012), Changes in the nutrient composition of the African oil bean meal "Ugba" (Pentaclethre Macrophylla Benth) subjected to solid state natural fermentation. Journal of Applied Biosciences, 51, 35913595 .

[16] C.U. Igwe, O.A. Ojiako, K.C. Anugweje, L.A. Nwaogu and C.O. Ujowundu (2012), Amino acid profile of raw and locally processed seeds of Prosopis africana and Ricinus communis: Potential antidotes to protein malnutrition. Function of Foods in Health and Disease, 2, 107-119.

[17] G. Wu (2010), Functional amino acids in growth, reproduction, and health. Advance in Nutrition, 1, 31-37.
[18] A. Bujang and N.A. Taib (2014), Changes on amino acids content in soybean, garbanzo bean and groundnut during pretreatments and Tempe making, Sains Malaysiana, 43, 551-557.

[19] B. Mohanty, A. Mahanty, S. Ganguly, T.V. Sankar, K. Chakraborty, A. Rangasamy and A.P. Sharma (2014), Amino acid compositions of 27 food fishes and their importance in clinical nutrition. Journal Amino Acids, 7, 1-8.

[20] M. Monirujjaman and A. Ferdouse (2014), Metabolic and physiological roles of branched-chain amino acids. Advances in Molecular Biology, 5, 6-11.

[21] D.M. Richard, M.A. Dawes, C.W. Mathias, A. Acheson, N. Hill-Kapturczak and D.M. Dougherty (2009), L-tryptophan: Basic metabolic functions, behavioral research and therapeutic indications. International Journal of Tryptophan Research, 2, 45-60.

[22] W. M. Furuya, M. Michelato, A. L. Salaro, T. P. da Cruz1, and V. R. BarrivieraFuruya, (2015), Estimation of the dietary essential amino acid requirements of colliroja Astyanax fasciatus by using the ideal protein concept. Latin American Journal of Aquatic Research, 43, 888-894.

[23] S.M. Liao, Q.S. Du, J.Z. Meng, Z.W. Pang and R.B. Huang (2013), The multiple roles of histidine in protein interactions. Chemistry Central Journal, 7, 44 - 51.

[24] J. Costa, C. Gomes and M. Carvalho (2010), Diagnosis, pathogenesis and therapeutic targets in amyotrophic lateral sclerosis. Neurological Disorders - Drug Targets, 9, 764-778.

[25] O.S. Ijarotimi and O.O. Keshinro (2012), Comparison between the amino acid, fatty acid, mineral and nutritional quality of raw, germinated and fermented African locust bean (Parkia biglobosa) flour. Science Pollination Technology Aliment, 11, 151-165. 
[26] W. Wang, Z. Wu, Z. Dai, Y.Yang, J. Wang and G. Wu (2013), Glycine metabolism in animals and humans: Implications for nutrition and health. Amino Acids, 45, 463-477.

[27] O.O. Oluwaniyi and I.O. Bazambo (2016), Nutritional and amino acid analysis of raw, partially fermented and completely fermented locust bean (Parkia biglobosa) seeds. African Journal of Food Agriculture, Nutrition and Development, 16, 10866 10883.

[28] A. Mahanty, S. Ganguly and A. Verma (2015), Nutrient profile of small indigenous fish Puntius Sophore: Proximate composition, amino acid, fatty acid and micronutrient profiles. National Academy Science Letters, 37, 39-44.

[29] B.I. Ogunyinka, E. Babatunji, B.E. Oyinloye, F.O. Osunsanmi, A.P. Kappo and A.R. Opoku (2017), Comparative study on proximate, functional, mineral and antinutrient composition of fermented, defatted and protein isolate of Parkia biglobosa seed. Food Science \& Nutrition, 5, 139-147.

[30] S.B. Yellavila, J.K. Agbenorhevi, J.Y. Asibuo and G.O. Sampson (2015), Proximate composition, minerals content and functional properties of five lima bean accessions. Journal of Food Security, 3, 6974.

[31] J.C. Ibeabuchi (2014), Proximate and functional properties of raw and fermented bottle gourd seed (Lagenaria siceraria). International Journal of Biotechnology and Food Science, 2, 82-87.

[32] I.E. Mbaeyi-Nwaoha and F.C. Obetta (2016), Production and evaluation of nutrient-dense complementary food from millet (Pennisetum glaucum), pigeon pea (Cajanus cajan) and seedless breadfruit (Artocarpus altillis) leaf powder blends. African Journal of Food Science, 10, 143 156.
[33] O.J. Adebowale and K. Maliki (2011), Effect of fermentation period on the chemical composition and functional properties of Pigeon pea (Cajanus cajan) seed flour. International Food Research Journal, 18, 1329-1333.

[34] M.Z.Islam, M.L.J. Taneya, M. ShamsUd-Din, M. Syduzzaman and M.M. Hoque (2012) Physicochemical and functional properties of brown rice (Oryza sativa) and wheat (Triticum aestivum) flour and quality of composite biscuit made thereof. A Scientific Journal of Krishi Foundation, 10, 20-28.

[35] I. Mohammed, A.R. Ahmed and B. Senge (2014), Effects of chickpea flour on wheat pasting properties and bread making quality. Journal of Food Science and Technology, 51, 1902-1910.

[36] G.O. Oyeleke, E.O. Olagunju and A. Ojo (2012), Functional and physicochemical properties of watermelon (Citrullus lanatus) seed and seed-oil. Journal of Applied Chemistry, 2, 29 - 31.

[37] E.S.D. Osagie-Eweka and T.H. Alaiya (2013), Effects of fermentation and heating on the functional properties of processed flour from African oil bean (Pentaclethra macrophylla Benth) seeds. African Journal of Food Agriculture, Nutritional and Development, 13, 8249 -8257.

[38] X.Mao and Y. Hua (2012), Composition, structure and functional properties of protein concentrates and isolates produced from walnut (Juglans regia L.). .). International. Journal of Molecular Science, 13, 1561-1581.

[39] B.D. Igbabul, F.A. Bello and E.C. Ani (2014), Effect of fermentation on the proximate composition and functional properties of defatted coconut (Cocos nucifera L.) flour. Sky Journal of Food Science, 3, $034-040$.

[40] E.M. Ogunbusola, T.N. Fagbemi and O.F. Osundahunsi (2012), Chemical and 
functional properties of full fat and defatted white melon (Cucumeropsis mannii) seed flours. Journal of Food Science and Engineering, 2, 691-696.

[41] O.L. Otutu, K.T. Seidu, B.O. Muibi, F. Oladokun and M.R. Oyalowo (2015), Potential food value of watermelon (Citrullus lanatus) seed constituents. The International Journal of Science \& Technoledgy, 3, $222-231$.

[42] F. Appiah, J.Y. Asibuo and P. Kumah (2011), Physicochemical and functional properties of bean flours of three cowpea (Vigna unguiculata L. Walp) varieties in Ghana. African Journal of Food Science, 5, $100-104$.

[43] A. Adejumo, I. Azeez, J. Geply and F. Oboite (2013), Processing, utilization and challenges of African locust bean (Parkia biglobosa, Jacque benth) in Arigidi Akoko, Ondo State, Nigeria. Journal of Agriculture and Social Research, 13, 23-34.

[44] O.S. Falade, S.A. Adekunle, M.A. Aderogba, S.A. Atanda, C. Harwood and S.R.A. Adewusi (2008), Physicochemical properties, total phenol land tocopherol of some Acacia seed oils. Journal of Science Food Agriculture, 88, 263-268.

[45] I.I. Nkafamiya, H.M. Maina, S.A. Osemeahon and U.U. Modibbo (2010), Percentage oil yield and physiochemical properties of different groundnut species (Arachis hypogaea). African Journal of Food Science, 4, 418 - 421.

[46] V.N. Atasie, T.F. Akinhanmi, and C.C. Oiodu (2009), Proximate analysis and physicochemical properties of groundnut (Arachis hypogaea L.). Pakistan Journal of Nutrition, 8, 194 - 197.

[47] S.S. Mohammed, Y.B. Paiko, A. Mann, J.T. Mathew, R.U. Hamzah and S. Mustapha (2013), Oil Characterization, Amino Acid and Vitamin $\mathrm{A}$ and $\mathrm{C}$ Composition of Cucurbita Maxima Seed obtained from
Sakpe, Niger State, Nigeria. Nigerian Journal of Chemical Research, 18, 40-47.

[48] O.I. Oluremi, A.O. Solomon and A.A. Saheed (2013), Fatty acids, metal composition and physico-chemical parameters of Igbemo Ekiti rice bran oil. Journal of Environmental Chemistry and Ecotoxicology, 5, 39-46.

[49] M.O. Bello, O.S. Falade, S.R.A. Adewusi and N.O. Olawore (2009), Studies on the chemical composition and antinutrients of some lesser known Nigeria fruits. African Journal of Biotechnology, 7, 3972-3979.

[50] S.S. Ochigbo and Y.B. Paiko (2011), Effects of solvent blending on the characteristic of oils extracted from the seeds of Chrysophyllum albidium. International Journal of Science and Nature, 2, 352-358.

[51] M.A. Shad, H. Pervez, Z.I. Zafar, H. Nawaz and H. Khan (2012), Physicochemical properties, fatty acid profile and antioxidant activity of peanut oil. Pakistan Journal of Botany, 44, 435-440.

[52] M.I. Mohammed and Z.U. Hamza (2008), Physicochemical properties of oil extracts from Sesamum Indicum $L$. seeds grown in Jigawa State-Nigeria. Journal of Applied Science and Environment Management, 12, 99-101.

[53] I.O. Akubugwo and A.E. Ugbogu (2007), Physicochemical studies on oils from five selected Nigerian plant seeds. Pakistan Journal of Nutrition, 6, 75-78.

[54] M.O. Bello, T.L. Akindele, D.O. Adeoye and A.O. Oladimeji (2011), Physicochemical properties and fatty acids profile of seed oil of Telfairia occidentalis Hook, F. International Journal of Basic \& Applied Sciences, 11, 9-14. 